\title{
Improving control of carbide-derived carbon microstructure by immobilization of a transition-metal catalyst within the shell of carbide/carbon core-shell structures
}

\author{
Teguh Ariyanto*1,2, Jan Glaesel ${ }^{2,3}$, Andreas Kern², Gui-Rong Zhang 2,3 \\ and Bastian J. M. Etzold ${ }^{\star 2,3}$
}

\section{Full Research Paper}

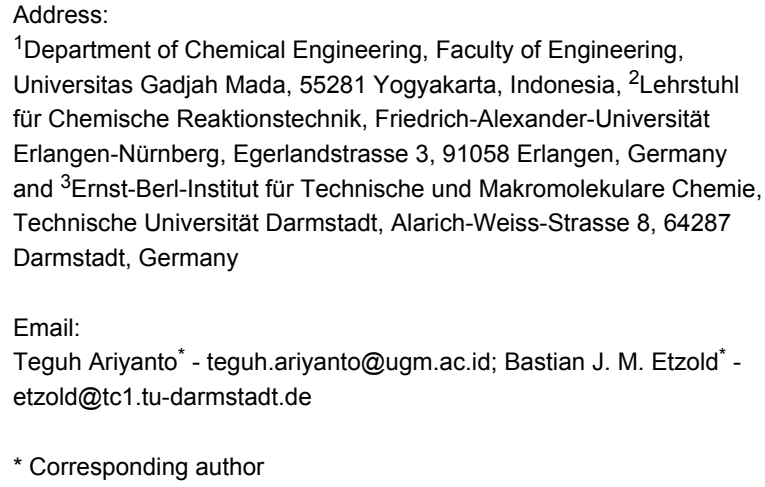

${ }^{1}$ Department of Chemical Engineering, Faculty of Engineering, Universitas Gadjah Mada, 55281 Yogyakarta, Indonesia, ${ }^{2}$ Lehrstuhl für Chemische Reaktionstechnik, Friedrich-Alexander-Universität Erlangen-Nürnberg, Egerlandstrasse 3, 91058 Erlangen, Germany and ${ }^{3}$ Ernst-Berl-Institut für Technische und Makromolekulare Chemie, Technische Universität Darmstadt, Alarich-Weiss-Strasse 8, 64287 Darmstadt, Germany

Email:

Teguh Ariyanto* - teguh.ariyanto@ugm.ac.id; Bastian J. M. Etzold etzold@tc1.tu-darmstadt.de

* Corresponding author

Keywords:

carbon shell; catalytic graphitization; graphitic carbon; pore structure; transition metal

\author{
Beilstein J. Nanotechnol. 2019, 10, 419-427. \\ doi:10.3762/bjnano.10.41
}

Received: 09 October 2018

Accepted: 17 January 2019

Published: 11 February 2019

This article is part of the thematic issue "Carbon-based nanomaterials for energy applications".

Guest Editor: J. J. Schneider

(C) 2019 Ariyanto et al.; licensee Beilstein-Institut. License and terms: see end of document.

\footnotetext{
Abstract

Carbon materials for electrical energy devices, such as battery electrodes or fuel-cell catalysts, require the combination of the contradicting properties of graphitic microstructure and porosity. The usage of graphitization catalysts during the synthesis of carbide-derived carbon materials results in materials that combine the required properties, but controlling the microstructure during synthesis remains a challenge. In this work, the controllability of the synthesis route is enhanced by immobilizing the transitionmetal graphitization catalyst on a porous carbon shell covering the carbide precursor prior to conversion of the carbide core to carbon. The catalyst loading was varied and the influence on the final material properties was characterized by using physisorption analysis with nitrogen as well as carbon dioxide, X-ray diffraction, temperature-programmed oxidation (TPO), Raman spectroscopy, SEM and TEM. The results showed that this improved route allows one to greatly vary the crystallinity and pore structure of the resulting carbide-derived carbon materials. In this sense, the content of graphitic carbon could be varied from 10-90 wt \% as estimated from TPO measurements and resulting in a specific surface area ranging from 1500 to $300 \mathrm{~m}^{2} \cdot \mathrm{g}^{-1}$.
} 


\section{Introduction}

Carbon is a versatile material that has been widely utilized in many applications such as adsorption [1-3], catalysis [4,5], catalyst support [6-8], molecular sieves $[9,10]$ and energy storage [11-13], owing to its large specific surface area and distinct pore character. For applications in which electrical conductivity plays an important role, e.g., battery electrodes, fuel-cell catalysts or supercapacitors [14-16], it is necessary for carbon to not only show porosity but also to feature a graphitic structure. The reason is that graphitic carbon consists of crystalline $\mathrm{sp}^{2}$ hybridized fractions that induce high electron conductivity. Moreover, an enhanced crystallinity is favorable in terms of chemical stability, which is required especially when working under harsh conditions.

Many synthetic approaches were employed to produce carbon combining porosity and graphitic structure [17-19]. Among them, the carbide-derived carbon (CDC) is a promising route. $\mathrm{CDC}$ can be synthesized through the selective extraction of metals or metalloid atoms from metal carbides $\left(\mathrm{Me}_{x} \mathrm{C}\right.$, e.g., TiC, $\mathrm{SiC}, \mathrm{VC}$, and $\mathrm{Mo}_{2} \mathrm{C}$ ) by using halogen gases at elevated temperatures. Depending on the carbide and parameters employed during the synthesis, CDC can be varied from extremely amorphous to highly crystalline microstructures and from ultramicro- to mesoporous pore structures. Therefore, CDC is known as material with tunable microstructure and pore structures [20].

To produce CDC with a high content of graphitic structure, there are two possibilities that can be applied (neglecting a postsynthesis treatment after CDC synthesis). The first is very high synthesis temperatures (ca. $1500{ }^{\circ} \mathrm{C}$ ) [4], which is, however, associated with a pronounced energy consumption for the reactor heating as well as with challenges to handle chlorine at such high temperatures. The second approach is using catalytic graphitization during the material synthesis. It typically requires only moderate temperatures (typically starting from $800{ }^{\circ} \mathrm{C}$, depending on types of carbides [19]). Commonly used graphitization catalysts are transitions metals such as $\mathrm{Fe}, \mathrm{Ni}$, and $\mathrm{Co}$ $[18,21,22]$. The conventional method for catalytic graphitization is to mix the non-porous carbide and metal catalyst precursor prior to the selective etching at high temperature. Indeed, the graphitic content is present, but the overall material is rather inhomogeneous $[18,23]$. Most likely the physical powder mixture or the simple dip coating of the powder carbide precursor with the transition-metal catalyst lead to a very inhomogeneous starting mixture, which is responsible for the final heterogeneous combination. Immobilizing the transition metal-catalyst at each particle would ensure a homogeneous catalytic graphitization of the whole powder samples.

We recently introduced the possibility to obtain core-shell particles in which a nanoporous carbon shell is covering a carbide core $[14,15,24,25]$. The porosity of this shell could suit for the immobilization of the transition-metal catalyst, as capillary forces would suck the impregnation solution within the shell and only excess solution would go into the voids between the particles. Subsequent chlorination of the carbide core to obtain carbide-derived carbon would be influenced by the transitionmetal catalyst in the shell of each particle. This work studies the use of core-shell carbon/carbide hybrids to immobilize different amounts of graphitization catalyst as illustrated in Figure 1. The resulting microstructure and pore structure of the carbon material is characterized by X-ray diffraction (XRD), temperature-programmed oxidation (TPO) and physisorption analysis.

\section{Results and Discussion Properties of CDC-shell/carbide core starting material}

First of all, the properties of the hybrid starting material (Figure 1, left) were studied. A partial conversion to obtain $30 \%$ shell and $70 \%$ core was set and confirmed by the mass loss recorded. Figure 2a shows a TEM image where clearly a porous carbon shell covering a carbide core is seen, which originates from the shrinking core like conversion mechanism in combination with the partial conversion $[15,26]$.

Figure $2 \mathrm{~b}$ shows the pore structure of the partially converted carbide at $800{ }^{\circ} \mathrm{C}$ characterized by $\mathrm{N}_{2}$ sorption analysis. The adsorption-desorption curve shows a similar shape compared to a typical fully CDC material synthesized at $800{ }^{\circ} \mathrm{C}$ but features a lower uptake due to the mass of the non-porous carbide core [15]. According to the IUPAC classification, the isotherm can

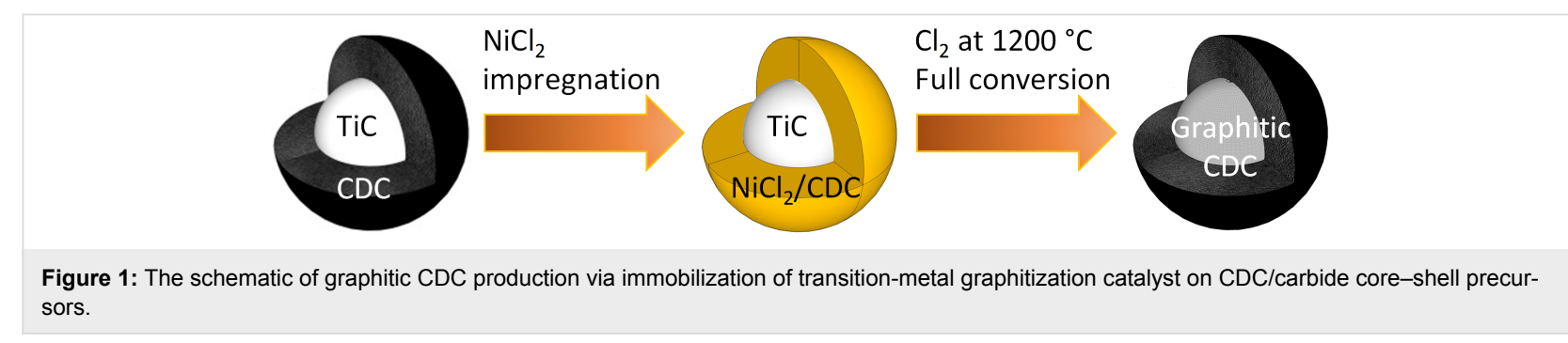


(a)

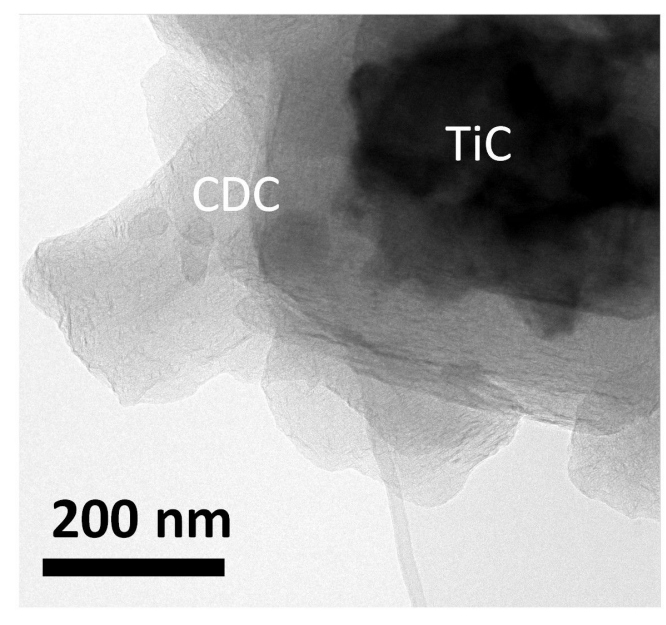

(b)

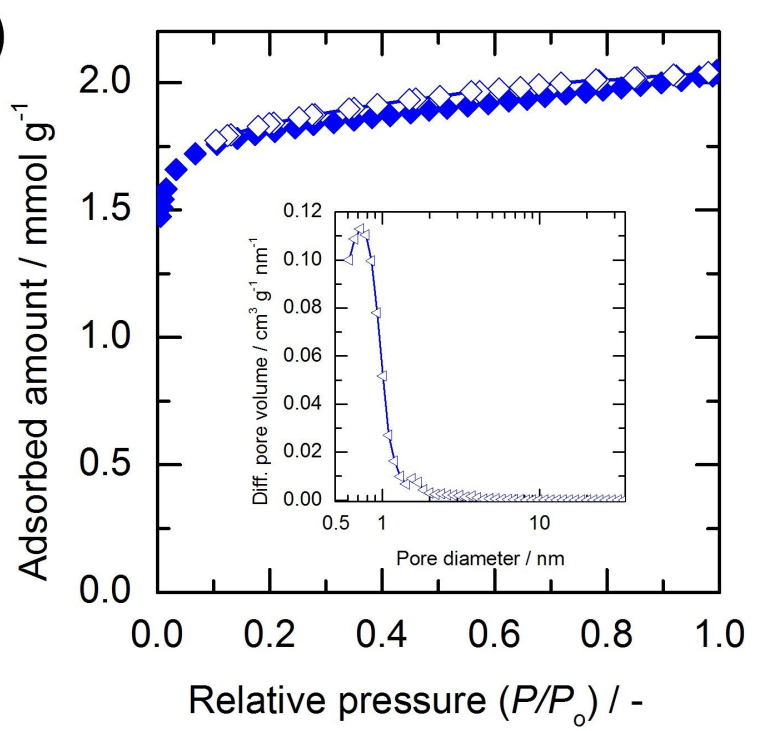

Figure 2: (a) TEM analysis of partially chlorinated carbide (CDC-shell) showing transparent CDC covering the carbide core; (b) $\mathrm{N}_{2}$-sorption isotherm of the CDC-shell and inset of its QSDFT pore size distribution.

be classified as type Ia suggesting a highly (ultra-)microporous material [27]. The pore size distribution (PSD) of the material was evaluated by using the quenched solid density functional theory (QSDFT) method (result displayed as inset in Figure 2b). CDC-shell contains mainly micropores ( 95 vol \%) with a high peak of differential pore volume centered at ca. $0.8 \mathrm{~nm}$. The surface area of CDC-shell is $160 \mathrm{~m}^{2} \cdot \mathrm{g}^{-1}$ per total mass of material (shell and core). It can be concluded from the pore analysis that the porous $\mathrm{CDC}$ was obtained by the partial chlorination of carbide. For more details, the pore textural parameters are summarized below in Table 1.

To study whether the shell of partially converted carbide influences the distribution of the nickel precursor after the impregnation step, the impregnation of untreated titanium carbide was compared with the same loading (30 mg of nickel per gram of equivalent carbide). EDX mapping (see Figure S1 in Supporting Information File 1) of the impregnated core-shell material shows clearly the remaining core in the Ti K edge signal, while the $\mathrm{Ni} \mathrm{K}$ and $\mathrm{Cl} \mathrm{K}$ edges show that nickel chloride is homogeneously immobilized within the shell. A clustering on top of the particle seems not to take place. In contrast, the SEM image of the untreated titanium carbide shows nickel chloride crystals covering the particles. This is further corroborated through the EDS mapping (Figure S2 in Supporting Information File 1).

\section{Influence of nickel loading on the microstructure of the final carbon material}

The porous-carbon-on-carbide-core material (CDC-shell) was impregnated with different amounts of nickel chloride hexahy- drate (Figure 1, middle) and further chlorinated at $1200{ }^{\circ} \mathrm{C}$ to obtain the final material (Figure 1, right). The amount of nickel added was varied from 5 up to $60 \mathrm{mg}$ of nickel per gram of equivalent carbide. The effect of nickel catalyst on the microstructure of final carbon was investigated using XRD, temperature-programmed oxidation (TPO), HRTEM and Raman spectroscopy.

The XRD patterns for the different catalyst loadings are given in Figure 3a. The CDC-Ni0 reference material shows no reflexes indicating an amorphous character, which is in agreement with the literature [15]. Once adding graphitization catalyst (CDC-Ni5 to CDC-Ni60) clearly graphitic reflexes of $\mathrm{C}(002)$ and $\mathrm{C}(100 / 101)$ at $2 \theta \approx 26^{\circ}$ and $2 \theta \approx 43^{\circ}$ and even of $\mathrm{C}(004)$ and $\mathrm{C}(110)$ are observable. Figure $3 \mathrm{a}$ also depicts that the diffraction peak intensity increases with higher nickel loading, indicating a larger portion of crystalline carbon with rising nickel content. To investigate further the effect of nickel loading to the crystallite dimension, the parallel and in-plane symmetry crystallite sizes corresponding to $\mathrm{C}(002)\left(2 \theta \approx 26^{\circ}\right)$ and $\mathrm{C}(100)\left(2 \theta \approx 43^{\circ}\right)$ were evaluated using the Scherrer equation (peak deconvolution, see Experimental section). It is noted that the Scherrer equation provides an only rough estimation of crystal dimensions but can serve as basis for the discussion of microstructural trends. The evaluation reveals that the crystallite dimensions, i.e., width $\left(L_{\mathrm{a}}\right)$ and height $\left(L_{\mathrm{c}}\right)$ for final CDC are largely independent of the amount of employed nickel catalyst (see Figure 3b). Despite the relative constant crystal sizes, the increasing intensity of the XRD reflexes indicates that the amount of crystalline carbon compared to amorphous phase is increasing with higher nickel loading. 

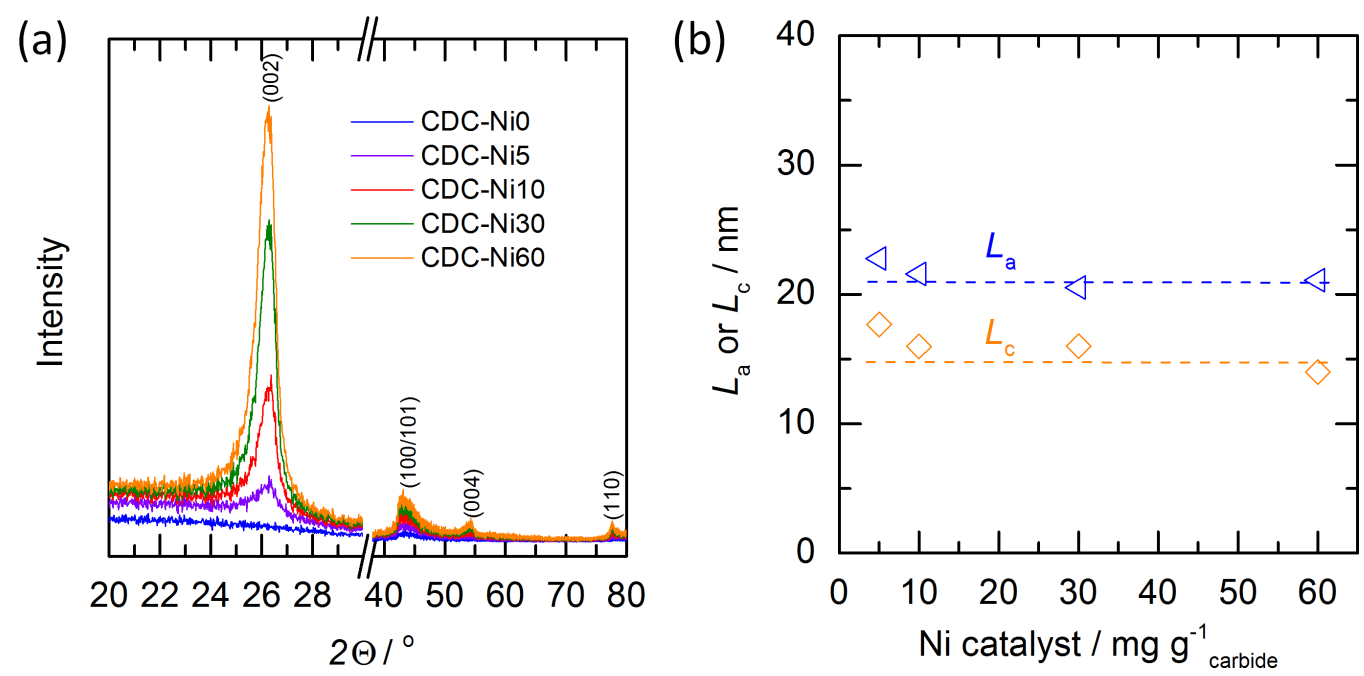

Figure 3: (a) XRD pattern and (b) the crystallite dimension for the in-plane $\left(L_{a}\right)$ and cross section of multi-layer carbons $\left(L_{c}\right)$ of final CDCs.

TPO was employed to probe the ratio between of amorphous and crystalline carbon, based on the different oxidation stability [4,28]. Differential mass-loss curves from the TPO analysis of materials with varying nickel loading are displayed in Figure $4 \mathrm{a}$. It can be seen that $\mathrm{CDC}-\mathrm{Ni} 0$ shows only a single oxidation peak with a maximum at approx. $596^{\circ} \mathrm{C}$. The CDC-Ni5 reference with the smallest amount of graphitization catalyst added, exhibits also a large signal with an oxidation peak of $595{ }^{\circ} \mathrm{C}$ and shows a second peak rising at approx. $700{ }^{\circ} \mathrm{C}$. With even higher nickel contents (CDC-Ni10 and higher) clearly two oxidation peaks can be distinguished, where the first peak corresponds to the more amorphous carbon obtained without adding catalyst (CDC-Ni0). It can therefore be speculated that the second peak at higher oxidation temperatures belongs to the graphitic domains generated with the nickel catalyst.
As there is a distinct separation of both peaks at $610{ }^{\circ} \mathrm{C}$, the TPO signal is divided into two areas, i.e., "Area I" in the region below $610^{\circ} \mathrm{C}$ and "Area II" in the region above $610^{\circ} \mathrm{C}$. From integrating both regions the ratio between amorphous and graphitic carbon can be roughly estimated. Figure $4 \mathrm{~b}$ plots this ratio as a function of the Ni catalyst loading. It can be clearly seen that the portion of crystalline carbon increases to $67 \%$ when adding 5 and $10 \mathrm{mg}$ of nickel per $\mathrm{g}$ of carbide. Adding more nickel $\left(30 \mathrm{mg} \cdot \mathrm{g}^{-1}\right)$ increases the ratio up to approx. $90 \%$ while a further increase to $60 \mathrm{mg} \cdot \mathrm{g}^{-1}$ shows no additional improvement.

TEM images of crushed particles of CDC-Ni0 and CDC-Ni60 are given in Figure 5 and support the findings. Clearly CDC$\mathrm{Ni} 0$ exhibits an amorphous character. The CDC-Ni60 exhibits
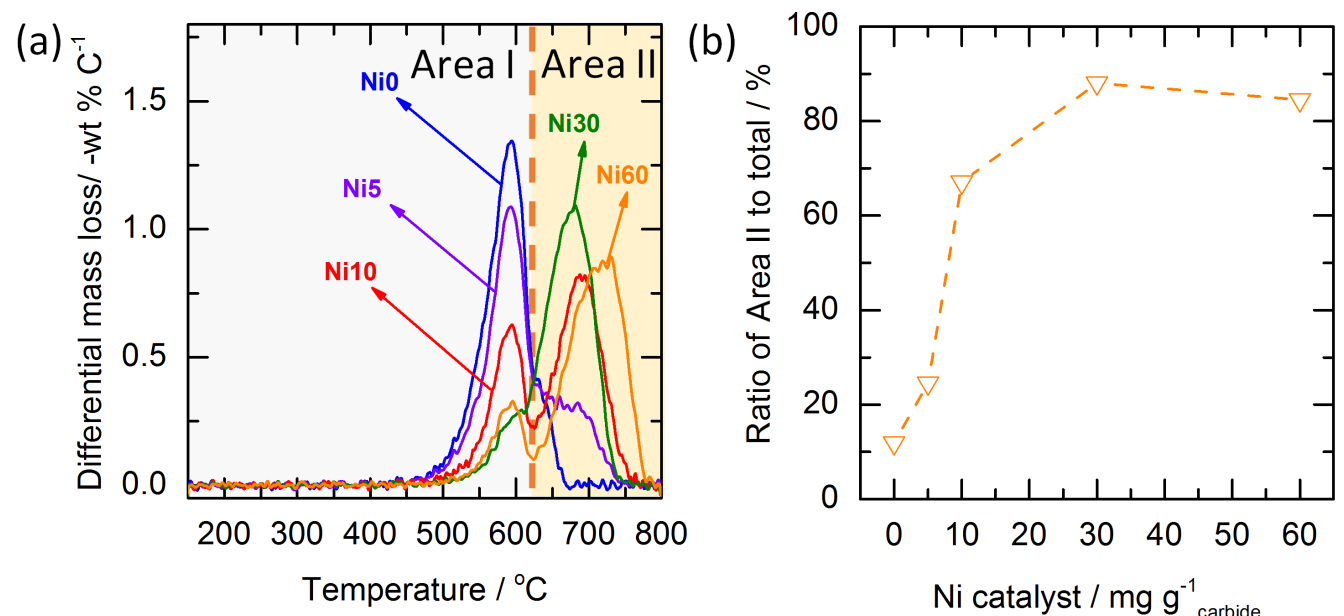

$\mathrm{Ni}$ catalyst $/ \mathrm{mg} \mathrm{g}^{-1}$ carbide

Figure 4: (a) Temperature-programmed oxidation profile of final CDC; (b) the calculated fraction of Area II representing content of more graphitic carbon. 
(a)

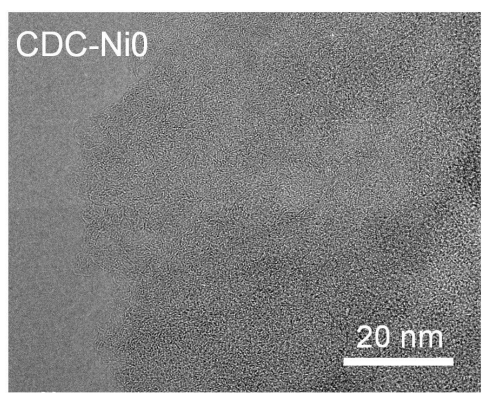

(b)

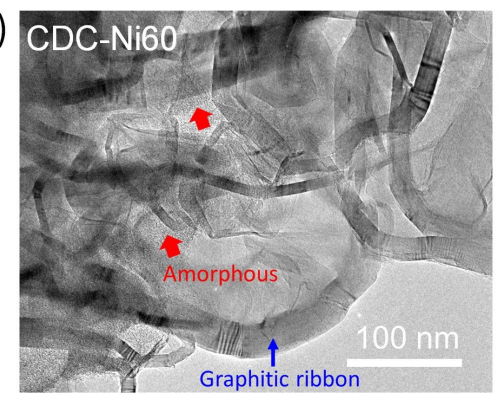

(c)

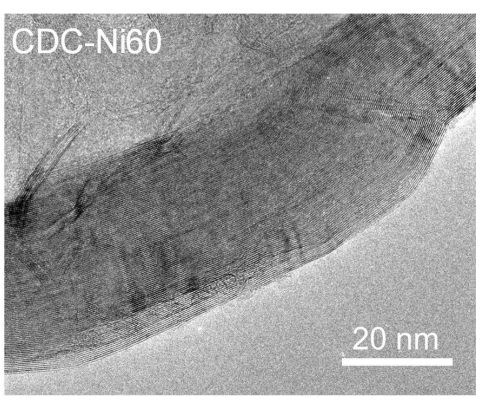

Figure 5: TEM images of CDC-NiO (a) and CDC-Ni60 (b,c).

graphitic character indicated by the formation of graphitic ribbons (Figure 5b). The stacking height corroborates the XRD diffractogram evaluation. Parallel fringes are seen in the magnification of the graphitic ribbons (Figure 5c). From the TEM study it seems that also for CDC-Ni60 some amorphous carbon is homogeneously distributed among the graphitic domains (Figure 5b). Raman spectra were recorded for CDC-Ni0, CDC$\mathrm{Ni} 10$ and CDC-Ni60 and are given in Supporting Information File 1 (Figure S3). Surprisingly, in contrast to TPO, XRD and TEM, no strong differences in crystallinity of the samples can be observed by using Raman spectroscopy. All spectra are characterized by the presence of two more or less overlapping Dand G-bands centered at ca. 1325 and $1583 \mathrm{~cm}^{-1}$. CDC-Ni0 shows a slightly higher level of disorder, while the spectra of CDC-Ni10 and CDC-Ni60 are similar. The reason for the deviation from the other characterization results could be the penetration depth of the Raman laser, which probably is probing especially the shell of the core-shell material. As the initial shell is produced without graphitization catalyst here, more amorphous carbon is expected. The Raman results indicate, that the initial amorphous shell is not strongly recrystallizing during the second chlorination step. This could be also the reason for the amorphous carbon detected in the TPO characterization even for high nickel loadings.

The results show that the loading of graphitization catalyst allows one to tune the content of crystalline carbon. Furthermore, if sufficient catalyst is immobilized within the porous shell, the whole particles seem to benefit from the graphitization catalyst. It also needs to be noted that in the final material no remaining nickel was found by XRD (Figure 3a), in the ash of the TPO measurements (see Figure S4 in Supporting Information File 1) or in the TEM images. The absence of nickel residues can be explained by the formation of volatile $\mathrm{NiCl}_{2}$ during the chlorination of the core at $1200{ }^{\circ} \mathrm{C}$ [29].

\section{Influence of nickel loading on the pore structure of the final carbon material}

Figure 6a shows the resulting nitrogen-sorption isotherms for varying amounts of nickel loading. The material without graphi-
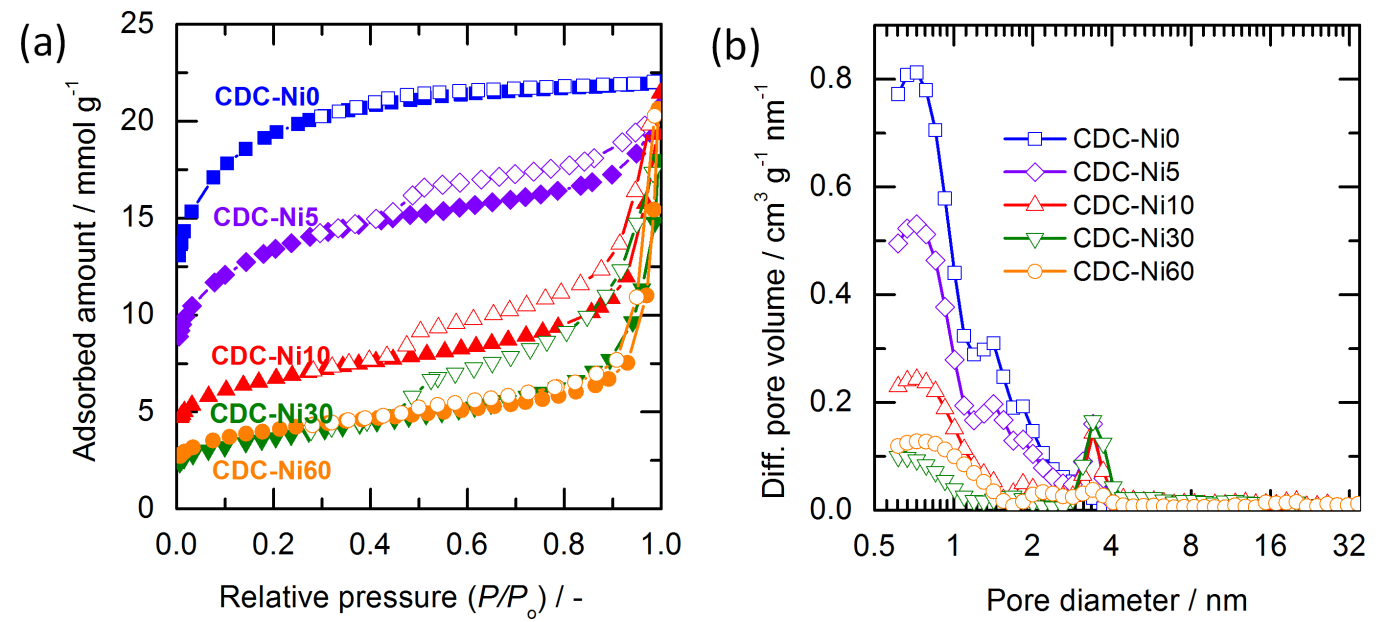

Figure 6: (a) $\mathrm{N}_{2}$-sorption isotherm of final CDC material (closed and open symbols show the adsorption and desorption branches, respectively); (b) Pore size distribution of final CDC evaluated by QSDFT method. 
tization catalyst (CDC-Ni0) shows an isotherm with a wider knee in the low-pressure range (type $\mathrm{Ib}$ ) isotherm, indicating a broad range of micropores. This is in accordance with pore size distributions obtained for TiC-CDC at $1200{ }^{\circ} \mathrm{C}[4,30]$. The addition of $5 \mathrm{mg}$ of nickel per gram of carbide (CDC-Ni5) already shows a pronounced influence on the resulting isotherm, which is a combination of type I and type II with a pronounced H3 hysteresis loop. It suggests that a larger pore exists in CDC-Ni5, which is likely induced by the graphitizing effect of the nickel catalyst, as described in [18,31]. Increasing the nickel loading from 5 to $30 \mathrm{mg} \cdot \mathrm{g}^{-1}$ carbide, leads to similar isotherm shapes but a decrease in the adsorbed volume of $\mathrm{N}_{2}$ in the low-pressure range. The pore size distributions evaluated by the QSDFT model are displayed in Figure 6b. CDC-Ni0 displays mainly pores in the micropore regime $(<2 \mathrm{~nm})$. On the other hand, the CDCs produced with the aid of the nickel catalyst show pores in the range of 3-4 nm, which are not present in the CDC-Ni0 sample.

The structural properties (specific surface area (SSA), total pore volume $\left(V_{\mathrm{T}}\right)$ and mean pore size $\left.\left(d_{\mathrm{m}}\right)\right)$ are summarized in Table 1. There are two types of SSA, $\mathrm{SSA}_{\mathrm{N} 2}$ and $\mathrm{SSA}_{\mathrm{CO} 2}$, obtained from nitrogen and carbon dioxide sorption analysis. Due to the low pressure of the $\mathrm{CO}_{2}$ analysis $\left(P / P_{0}=2.9 \times 10^{-2}\right)$, only pores in the micropore regime up to $1.5 \mathrm{~nm}$ can be probed [32]. Therefore, the mesopore/macropore structures can be roughly estimated by subtracting the contribution of micropore structures $\left(\mathrm{CO}_{2}\right.$ sorption) from the total pore structures $\left(\mathrm{N}_{2}\right.$ sorption). The reference of $\mathrm{CDC}-\mathrm{Ni} 0$ features $\mathrm{SSA}_{\mathrm{N} 2}$ of ca. $1500 \mathrm{~m}^{2} \cdot \mathrm{g}^{-1}$ and a mean pore size of $0.94 \mathrm{~nm}$. CDC-Ni5 displays a lower surface area of ca. $1000 \mathrm{~m}^{2} \cdot \mathrm{g}^{-1}$, which is caused by the presence of larger pores as a consequence of the nickel catalyst. The mean pore size of CDC-Ni5 increases by $32 \%$ compared to the CDC-Ni0. The specific surface area follows a reverse trend with respect to the nickel content (up to $30 \mathrm{mg} \cdot \mathrm{g}^{-1}$ carbide), but the average pore size increases, e.g., it is $3.53 \mathrm{~nm}$ for $\mathrm{CDC}-\mathrm{Ni} 30$ and therefore more than three times as large as that of pristine $\mathrm{CDC}-\mathrm{Ni}$. The results of $\mathrm{CO}_{2}$ sorp- tion analysis corroborate the finding that the micropore portion decreases from 86 to 13 vol \% when employing nickel loadings of $0-30 \mathrm{mg} \cdot \mathrm{g}^{-1}$ carbide. Interestingly, increasing the nickel loading from 30 to $60 \mathrm{mg} \cdot \mathrm{g}^{-1}$ does not lead to strong changes in the pore structure. In accordance with the TPO results, where the ratio of amorphous to graphitic carbon also did not change further, it can be speculated that $30 \mathrm{mg} \cdot \mathrm{g}^{-1}$ of nickel are the maximum amount of catalyst needed for full graphitization.

\section{Conclusion}

A new synthesis strategy to obtain graphitic CDC was introduced in which nickel as graphitization catalyst is immobilized on a porous shell covering each particle. This approach allows one to vary the ratio of graphitic to amorphous carbon in the final material through the amount of immobilized nickel. Increasing the loading up to $30 \mathrm{mg}_{\mathrm{Ni}} \mathrm{g}^{-1}$ carbide increased the graphitic content from 10 to $90 \%$ as estimated from TPO measurements, while the crystalline character (stacking height and width) is independent of the graphitic portion. This has a direct influence on the resulting pore structure showing a decreasing amount of micropores and increasing amount of mesoand macropores. Increasing the nickel loading above $30 \mathrm{mg}_{\mathrm{Ni}} \cdot \mathrm{g}^{-1}$ carbide did not change the material properties further and probably additional nickel can be seen to some extent as inert material not participating in the conversion. The new synthesis route seems to result in more homogeneous materials and allows for a better control of the final material properties.

\section{Experimental \\ Materials}

Commercial TiC ( $d_{\text {ave }}$ of $90 \mu \mathrm{m}, 99.8 \%$, Goodfellow) was employed as carbon precursor. Chlorine (purity 2.8, Linde AG) and hydrogen (purity 5.0, Linde AG) diluted by helium (purity 4.6, Linde $A G$ ) were used to perform reactive extraction of carbide (chlorination) and subsequent carbon surface annealing. Nickel chloride hexahydrate (99.95\% purity, Alfa Aesar) was used as precursor of the Ni catalyst.

\begin{tabular}{|c|c|c|c|c|c|c|}
\hline sample & $\begin{array}{l}\mathrm{SSA}_{\mathrm{N} 2}{ }^{\mathrm{a}} \\
{\left[\mathrm{m}^{2} / \mathrm{g}\right]}\end{array}$ & $\begin{array}{l}V_{\mathrm{T}} \\
{\left[\mathrm{cm}^{3} / \mathrm{g}\right]}\end{array}$ & $\begin{array}{l}d_{\mathrm{m}}^{\mathrm{b}} \\
{[\mathrm{nm}]}\end{array}$ & $\begin{array}{l}\mathrm{SSA}_{\mathrm{CO} 2}{ }^{\mathrm{c}} \\
{\left[\mathrm{m}^{2} / \mathrm{g}\right]}\end{array}$ & $\begin{array}{l}V_{\mathrm{CO}^{2}}{ }^{d} \\
{\left[\mathrm{~cm}^{3} / \mathrm{g}\right]}\end{array}$ & $\begin{array}{l}V_{\mathrm{CO} 2} / V_{\mathrm{T}} \\
{[\%]}\end{array}$ \\
\hline CDC-shell & 160 & 0.07 & 0.81 & 157 & 0.06 & 86 \\
\hline CDC-NiO & 1494 & 0.71 & 0.94 & 1278 & 0.47 & 66 \\
\hline CDC-Ni5 & 1030 & 0.64 & 1.24 & 785 & 0.29 & 45 \\
\hline CDC-Ni10 & 533 & 0.60 & 2.24 & 423 & 0.16 & 27 \\
\hline CDC-Ni30 & 297 & 0.52 & 3.53 & 176 & 0.07 & 13 \\
\hline CDC-Ni60 & 309 & 0.45 & 2.92 & 258 & 0.10 & 22 \\
\hline
\end{tabular}

aSpecific surface area obtained by $\mathrm{N}_{2}$-sorption analysis, ${ }^{b}$ mean slit-pore size, $\left(d_{m}\right)=2 V_{T} / S S A_{N 2}$, ${ }^{s p e c i f i c ~ s u r f a c e ~ a r e a ~ o b t a i n e d ~ b y ~} C_{2}$ sorption analysis, ${ }^{\mathrm{d}}$ pore volume taken from $\mathrm{CO}_{2}$ sorption analysis. 


\section{Synthesis of carbon shell/carbide core starting material}

The synthesis of hybrid particles where carbide cores are covered with a porous carbon shell, was reported previously in detail [15]. Briefly, a vertical quartz tube reactor $\left(d_{\mathrm{i}}=0.034 \mathrm{~m}\right.$, $l=1 \mathrm{~m}$ ) was employed to perform partial chlorination of carbide to carbon. About $1 \mathrm{~g}$ of TiC powder was loaded on the top of a quartz frit of a quartz tube. The reactor was then placed in an isothermal zone of the vertical furnace (Gero Company, Germany). After the tightness of reactor was verified, the reactor was heated to $800{ }^{\circ} \mathrm{C}$ under helium flow (superficial velocity, $v=0.015 \mathrm{~m} \cdot \mathrm{s}^{-1}$ ) with a heating rate of $10^{\circ} \mathrm{C} \cdot \mathrm{min}^{-1}$. The chlorination reaction was then carried out at $800{ }^{\circ} \mathrm{C}$ by dosing chlorine $\left(0.5 \mathrm{~mol} \cdot \mathrm{m}^{-3} \mathrm{Cl}_{2}\right.$ diluted in helium, $v=0.015 \mathrm{~m} \cdot \mathrm{s}^{-1}$ ) for $30 \mathrm{~min}$ reaction time. The chlorine flow was then stopped, and the reactor was flushed with helium. To remove residual chlorine in the pores, the sample was subsequently treated with $0.5 \mathrm{~mol} \cdot \mathrm{m}^{-3}$ hydrogen. Eventually, the reactor was cooled down to ambient temperature under helium purge. The carbon shell/carbide core intermediate produced is denominated as CDC-shell.

\section{Impregnation of nickel in carbon shell/carbide core starting material}

The nickel precursor was loaded to CDC-shell through wet impregnation, i.e., about $1 \mathrm{~g}$ of CDC-shell was mixed with a defined amount of nickel chloride hexahydrate dissolved in $3 \mathrm{~mL}$ ethanol. The solution was homogenized by ultrasonication for $30 \mathrm{~min}$. The solvent was evaporated, and the nickel chloride-loaded CDC-shell was dried in an oven at $60{ }^{\circ} \mathrm{C}$ overnight. The loading of nickel on CDC-shell (wt Ni/wt equivalent carbide) was set to $5,10,30$, and $60 \mathrm{mg} \cdot \mathrm{g}^{-1}$ carbide The equivalent mass of carbide $\left(m_{\mathrm{TiC}}\right)$ is determined using Equation 1.

$$
m_{\mathrm{TiC}}=\frac{m_{\mathrm{CDC}-\mathrm{shell}}}{\left(1-X \frac{M_{\mathrm{Ti}}}{M_{\mathrm{TiC}}}\right)}
$$

where $m_{\mathrm{CDC} \text {-shell }}$ is the mass of carbon shell/carbide core starting material, $X$ is the conversion rate, and $M_{\mathrm{Ti}}$ and $M_{\mathrm{TiC}}$ are the molar weight of $\mathrm{Ti}$ and $\mathrm{TiC}$, respectively.

\section{Synthesis of final carbide-derived carbon}

The Ni/CDC-shell was further chlorinated at $1200^{\circ} \mathrm{C}$ to complete the conversion of the carbide to the carbon. This reactive extraction was carried out using a horizontal chlorination setup as described in [4]. The reaction conditions were set to $3 \mathrm{~cm} \cdot \mathrm{s}^{-1}$ superficial velocity, $1 \mathrm{~mol} \cdot \mathrm{m}^{-3}$ chlorine and $3 \mathrm{~h}$ reaction time. To remove residual chlorine, an annealing treatment using hydrogen $\left(0.5 \mathrm{~mol} \cdot \mathrm{m}^{-3}\right)$ again was carried out after the extractive reaction. The nomenclature of the final carbon material obtained is "CDC" followed by "Ni" and catalyst loading. For instance, $\mathrm{CDC}-\mathrm{Ni} 30$ refers to the $\mathrm{CDC}$ material prepared by i) impregnation of CDC-shell with $\mathrm{NiCl}_{2} \cdot 6 \mathrm{H}_{2} \mathrm{O}$ with $30 \mathrm{mg} \mathrm{Ni} \cdot \mathrm{g}^{-1} \mathrm{CDC}$-shell and ii) chlorination until full conversion of $\mathrm{Ni} / \mathrm{CDC}$-shell at $1200^{\circ} \mathrm{C}$.

\section{Characterization methods}

The pore structure of CDC-shell and final CDC materials was characterized by $\mathrm{N}_{2}$ sorption at $-196{ }^{\circ} \mathrm{C}$ using liquid nitrogen as coolant (Quantachrome Quadrasorb Si-MP) and $\mathrm{CO}_{2}$ sorption measurements at $0{ }^{\circ} \mathrm{C}$ using a cryostat (Quantachrome Nova $4200 \mathrm{e})$. Before the measurement, the sample was degassed at $250{ }^{\circ} \mathrm{C}$ for $4 \mathrm{~h}\left(\mathrm{~N}_{2}\right.$ sorption) or $100{ }^{\circ} \mathrm{C}$ for $24 \mathrm{~h}$ ( $\mathrm{CO}_{2}$ sorption). The pore size distributions were evaluated from the sorptionisotherm data by using quenched solid density functional theory (QSDFT) equilibrium models for carbon with slit-shaped pores [33] provided by the QuadraWin 5.04 software (Quantachrome Instruments, USA). Temperature-programmed oxidation measurements (TPO) of the carbon materials were recorded in a Netzsch STA 409 PC Luxx (Germany) under air flow. The method consisted of isothermal drying at $150{ }^{\circ} \mathrm{C}$ for $1 \mathrm{~h}$ followed by heating from 150 to $800{ }^{\circ} \mathrm{C}$ at a constant ramp rate of $2.5^{\circ} \mathrm{C} \cdot \mathrm{min}^{-1}$. Peak deconvolution of the TPO curves was carried out with two bi-Gaussian functions. Raman spectra were taken using Jobin Yvon HR 800 with a HeNe laser (633 nm and $20 \mathrm{~mW}$ power). Peak deconvolution of Raman spectra was carried by peak fitting with four Lorentzian/Gaussian functions as described in [15]. Energy-dispersive spectroscopy (EDS) measurements were performed on a scanning electron microscope (Philips XL30 FEG, $30 \mathrm{kV}$ ) equipped with an EDAX $\mathrm{X}$-ray detector. Transmission electron microscopy (TEM) images were captured using a JEOL JEM-2100F microscope operated at $200 \mathrm{kV}$. The TEM samples were prepared by placing a drop of catalyst powder dispersion in deionized water onto a carbon-coated Au grid (G200F1, Quantifoil), followed by drying under ambient conditions. XRD patterns were recorded using a Philips X'pert Pro by PANalytical, Netherlands (40 kV and $40 \mathrm{~mA}$ using $\mathrm{Cu}$ Ka radiation). The XRD diffractograms were recorded in the $2 \theta$ range of $2-80^{\circ}$ in steps of $0.03^{\circ}$ with an acquisition time of $5 \mathrm{~s}$ per step. The XRD diffractograms were deconvoluted to evaluate the properties of graphitic reflexes (see exemplary deconvolution in Figure 7).

The graphite dimension $\left(L_{\mathrm{a}}\right.$ of the in-plane and $L_{\mathrm{c}}$ of the cross section size) was evaluated by the Scherrer equation shown in Equation 2 [34].

$$
L_{\mathrm{a} / \mathrm{c}}=\frac{K \lambda}{\beta \cos \theta},
$$



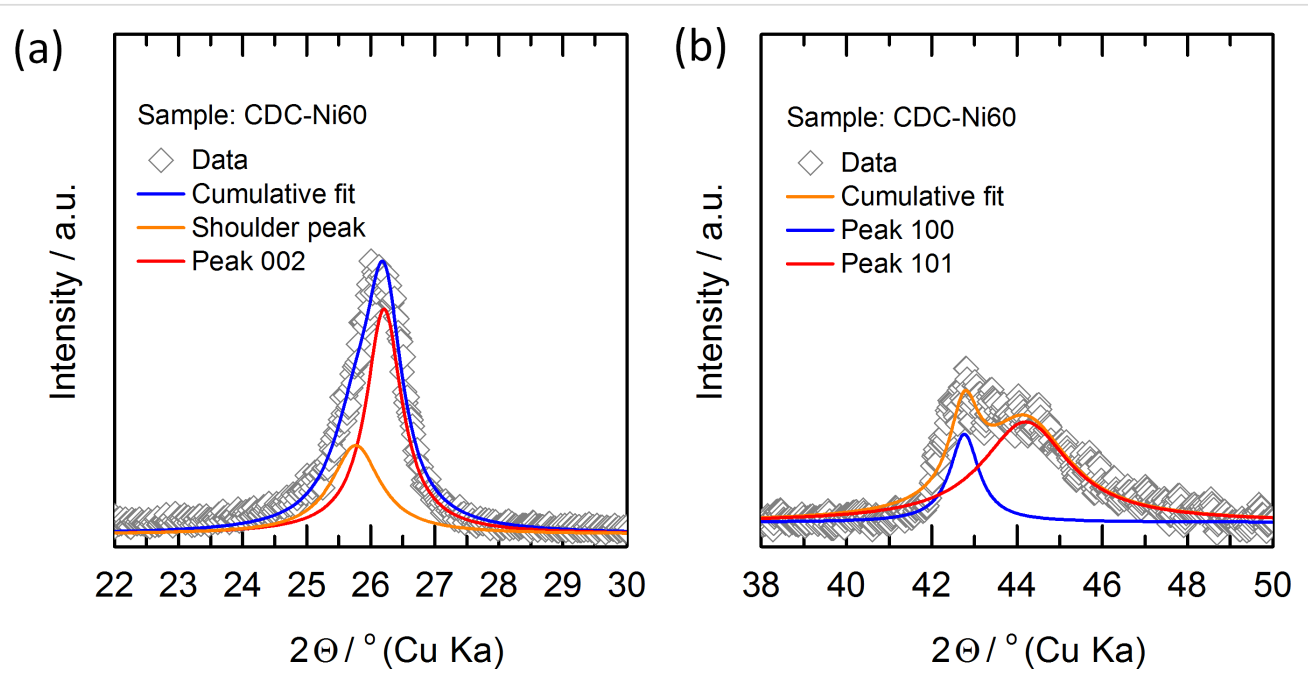

Figure 7: Examples of peak deconvolutions of XRD diffractograms at (a) $C(002)$ and (b) $C(100 / 101)$.

where $\lambda$ is the $\mathrm{X}$-ray wavelength $(0.154 \mathrm{~nm}), \theta$ is the diffraction angle, $\beta$ is the full width at half maximum (FWHM) of the deconvoluted peak in radian units and $K$ is a constant $(K=1.84$ for $L_{\mathrm{a}}$ at $\mathrm{C}(100 / 101)$ and $K=0.89$ for $L_{\mathrm{c}}$ at $\left.\mathrm{C}(002)\right)$.

\section{Supporting Information}

\section{Supporting Information File 1}

Additional data on SEM-EDX, Raman spectroscopy and temperature-programmed oxidation.

[https://www.beilstein-journals.org/bjnano/content/ supplementary/2190-4286-10-41-S1.pdf]

\section{Acknowledgements}

We acknowledge the funding of part of the research by the Deutsche Forschungsgemeinschaft (DFG, German Research Foundation) within the project ET-101/14-1.

\section{ORCID ${ }^{\circledR}$ iDs}

Teguh Ariyanto - https://orcid.org/0000-0002-9454-9541 Jan Glaesel - https://orcid.org/0000-0002-9301-8685 Bastian J. M. Etzold - https://orcid.org/0000-0001-6530-4978

\section{References}

1. Kameda, T.; Ito, S.; Yoshioka, T. J. Dispersion Sci. Technol. 2017, 38, 1063-1066. doi:10.1080/01932691.2016.1219953

2. Altenor, S.; Carene, B.; Emmanuel, E.; Lambert, J.; Ehrhardt, J.-J.; Gaspard, S. J. Hazard. Mater. 2009, 165, 1029-1039. doi:10.1016/j.jhazmat.2008.10.133

3. Yi, H.; Li, F.; Ning, P.; Tang, X.; Peng, J.; Li, Y.; Deng, H. Chem. Eng. J. 2013, 215-216, 635-642. doi:10.1016/j.cej.2012.11.050
4. Gläsel, J.; Diao, J.; Feng, Z.; Hilgart, M.; Wolker, T.; Su, D. S.; Etzold, B. J. M. Chem. Mater. 2015, 27, 5719-5725. doi:10.1021/acs.chemmater.5b02262

5. Wang, L.; Yao, Y.; Zhang, Z.; Sun, L.; Lu, W.; Chen, W.; Chen, H. Chem. Eng. J. 2014, 251, 348-354. doi:10.1016/j.cej.2014.04.088

6. Faria, P. C. C.; Órfão, J. J. M.; Pereira, M. F. R. Appl. Catal., B 2009, 88, 341-350. doi:10.1016/j.apcatb.2008.11.002

7. Kirilin, A. V.; Hasse, B.; Tokarev, A. V.; Kustov, L. M.; Baeva, G. N.; Bragina, G. O.; Stakheev, A. Y.; Rautio, A.-R.; Salmi, T.;

Etzold, B. J. M.; Mikkola, J.-P.; Murzin, D. Y. Catal. Sci. Technol. 2014, 4, 387-401. doi:10.1039/c3cy00636k

8. Munoz, M.; Zhang, G.-R.; Etzold, B. J. M. Appl. Catal., B 2017, 203, 591-598. doi:10.1016/j.apcatb.2016.10.062

9. Prasetyo, I.; Rochmadi, R.; Wahyono, E.; Ariyanto, T. Eng. J. 2017, 21, 83-94. doi:10.4186/ej.2017.21.4.83

10. Silvestre-Albero, A.; Rico-Francés, S.; Rodríguez-Reinoso, F.; Kern, A. M.; Klumpp, M.; Etzold, B. J. M.; Silvestre-Albero, J. Carbon 2013, 59, 221-228. doi:10.1016/j.carbon.2013.03.012

11. Sevilla, M.; Foulston, R.; Mokaya, R. Energy Environ. Sci. 2010, 3, 223-227. doi:10.1039/b916197j

12. Prasetyo, I.; Rochmadi, R.; Ariyanto, T.; Yunanto, R. Indones. J. Chem. 2013, 13, 95-100. doi:10.22146/ijc.21290

13. Gütlein, S.; Burkard, C.; Zeilinger, J.; Niedermaier, M.; Klumpp, M.; Kolb, V.; Jess, A.; Etzold, B. J. M. Environ. Sci. Technol. 2015, 49, 672-678. doi:10.1021/es504141t

14. Zeiger, M.; Ariyanto, T.; Krüner, B.; Peter, N. J.; Fleischmann, S.; Etzold, B. J. M.; Presser, V. J. Mater. Chem. A 2016, 4, 18899-18909. doi:10.1039/c6ta08900c

15. Ariyanto, T.; Dyatkin, B.; Zhang, G.-R.; Kern, A.; Gogotsi, Y.; Etzold, B. J. M. Microporous Mesoporous Mater. 2015, 218, 130-136. doi:10.1016/j.micromeso.2015.07.007

16. Schlange, A.; dos Santos, A. R.; Hasse, B.; Etzold, B. J. M.; Kunz, U.; Turek, T. J. Power Sources 2012, 199, 22-28. doi:10.1016/j.jpowsour.2011.09.107

17. Jin, H.; Li, J.; Gao, L.; Chen, F.; Zhang, H.; Liu, Q. Int. J. Hydrogen Energy 2016, 41, 9204-9210. doi:10.1016/j.ijhydene.2016.04.081

18. Kormann, M.; Gerhard, H.; Zollfrank, C.; Scheel, H.; Popovska, N. Carbon 2009, 47, 2344-2351. doi:10.1016/j.carbon.2009.04.018 
19. Sevilla, M.; Fuertes, A. B. Carbon 2006, 44, 468-474. doi:10.1016/j.carbon.2005.08.019

20. Gogotsi, Y.; Nikitin, A.; Ye, H.; Zhou, W.; Fischer, J. E.; Yi, B.; Foley, H. C.; Barsoum, M. W. Nat. Mater. 2003, 2, 591-594. doi:10.1038/nmat957

21. Jeong, J.-H.; Bae, H.-T.; Lim, D.-S. Carbon 2010, 48, 3628-3634. doi:10.1016/j.carbon.2010.06.017

22. Borchardt, L.; Hasché, F.; Lohe, M. R.; Oschatz, M.; Schmidt, F.; Kockrick, E.; Ziegler, C.; Lescouet, T.; Bachmatiuk, A.; Büchner, B.; Farrusseng, D.; Strasser, P.; Kaskel, S. Carbon 2012, 50, 1861-1870. doi:10.1016/j.carbon.2011.12.036

23. Xu, J.; Zhang, R.; Ge, S.; Wang, J.; Liu, Y.; Chen, P. Mater. Chem. Phys. 2013, 141, 540-548. doi:10.1016/j.matchemphys.2013.05.059

24. Ariyanto, T.; Kern, A. M.; Etzold, B. J. M.; Zhang, G.-R. Electrochem. Commun. 2017, 82, 12-15. doi:10.1016/j.elecom.2017.07.010

25. Ariyanto, T.; Zhang, G.-R.; Riyahi, F.; Gläsel, J.; Etzold, B. J. M. Carbon 2017, 115, 422-429. doi:10.1016/j.carbon.2017.01.032

26. Knorr, T.; Kaiser, M.; Glenk, F.; Etzold, B. J. M. Chem. Eng. Sci. 2012, 69, 492-502. doi:10.1016/j.ces.2011.11.002

27. Thommes, M.; Kaneko, K.; Neimark, A. V.; Olivier, J. P.; Rodriguez-Reinoso, F.; Rouquerol, J.; Sing, K. S. W. Pure Appl. Chem. 2015, 87, 1051-1069. doi:10.1515/pac-2014-1117

28. Pérez, C. R.; Yeon, S.-H.; Ségalini, J.; Presser, V.; Taberna, P.-L.; Simon, P.; Gogotsi, Y. Adv. Funct. Mater. 2013, 23, 1081-1089. doi:10.1002/adfm.201200695

29. Galetz, M. C.; Rammer, B.; Schütze, M. Mater. Corros. 2015, 66 , 1206-1214. doi:10.1002/maco.201408130

30. Presser, V.; Heon, M.; Gogotsi, Y. Adv. Funct. Mater. 2011, 21, 810-833. doi:10.1002/adfm.201002094

31. Leis, J.; Perkson, A.; Arulepp, M.; Nigu, P.; Svensson, G. Carbon 2002 , 40, 1559-1564. doi:10.1016/s0008-6223(02)00019-2

32. Schmirler, M.; Glenk, F.; Etzold, B. J. M. Carbon 2011, 49, 3679-3686. doi:10.1016/j.carbon.2011.05.003

33. Gor, G. Y.; Thommes, M.; Cychosz, K. A.; Neimark, A. V. Carbon 2012, 50, 1583-1590. doi:10.1016/j.carbon.2011.11.037

34. Dinnebier, R. E.; Billinge, S. J. L., Eds. Powder Diffraction; Royal Society of Chemistry: Cambridge, United Kingdom, 2008. doi:10.1039/9781847558237

\section{License and Terms}

This is an Open Access article under the terms of the Creative Commons Attribution License (http://creativecommons.org/licenses/by/4.0). Please note that the reuse, redistribution and reproduction in particular requires that the authors and source are credited.

The license is subject to the Beilstein Journal of Nanotechnology terms and conditions: (https://www.beilstein-journals.org/bjnano)

The definitive version of this article is the electronic one which can be found at:

doi:10.3762/bjnano.10.41 